\title{
PREDIKSI PERILAKU POLA JUMLAH MAHASISWA MENGGUNAKAN JARINGAN SYARAF TIRUAN DENGAN METODE BACKPROPAGATION
}

\author{
Yustria Handika Siregar \\ Universitas Asahan; Jln. Jend. Ahmad Yani, telp/fax (0623)347222 \\ Jurusan Teknik Informatika, Fakultas Teknik UNA, Kisaran Sumatera Utara \\ E-Mail : yustriahandikasiregar@gmail.com
}

\begin{abstract}
ABSTRAK - Penelitian ini bertujuan untuk memprediksi perilaku pola mahasiswa sehingga dapat memprediksi berdasarkan jumlah mahasiswa. Untuk mencapai output yang optimal maka penelitian ini menggunakan Jaringan Syaraf Tiruan dengan metode Backpropagation. Studi kasus yang dilakukan di Fakultas Teknik Universitas Asahan. Data yang digunakan adalah data jumlah mahasiswa pada tahun ajaran $2011 \mathrm{~s} / \mathrm{d} 2013$ sebagai data training dan data tahun ajaran $2014 \mathrm{~s} / \mathrm{d}$ 2016 sebagai data testing. Selanjutnya, data dianalisa dengan beberapa pola arsitektur jaringan dan pola yang terbaik akan dipilih untuk diimplementasikan ke program Matlab R2010. Hasil sistem menunjukkan korelasi antara jumlah mahasiswa yang terjadi.
\end{abstract}

Kata Kunci $\quad$ : Prediksi, Jaringan Syaraf Tiruan, Metode Backpropagation, Jumlah Mahasiswa

ABSTRACT - This study aims to predict student behavior patterns so that they can predict based on the number of students. To achieve optimal output, this study uses an Artificial Neural Network with Backpropagation method. A case study conducted at the Asahan University Faculty of Engineering. The data used is the data of the number of students in the school year 2011 to 2013 as training data and data from 2014 to 2016 as testing data. Next, the data is analyzed with several network architecture patterns and the best pattern will be chosen to be implemented to the Matlab R2010 program. The system results show a correlation between the number of students that occur.

Keywords: Prediction, Artificial Neural Networks, Backpropagation Method, Number of Students

\section{PENDAHULUAN}

Peminatan Fakultas Teknik semakin meningkat. Dari peningkatan tersebut, akibatnya persaingan pun juga semakin meningkat sehingga dibutuhkan strategi promosi yang matang. Pada umumnya, sistem promosi melihat dari jumlah mahasiswa pada program studi tersebut yang dapat dijadikan sebagai tolak ukur keberhasilan Fakultas tersebut. Jumlah setiap tahun ajaran pasti berbeda-beda. Fakultas tersebut pun mencari solusi untuk meningkatkan jumlah mahasiswa, mulai dari promosi besar-besaran.

Akibat dari pola jumlah mahasiswa yang terjadi setiap tahunnya berbeda-beda, maka diperlukan sistem yang dapat memprediksi kemungkinan jumlah mahasiswa yang terjadi di masa yang akan datang. Prediksi sendiri sebenarnya memperkirakan data yang akan dihasilkan pada masa yang akan datang dengan menggunakan data-data yang terjadi sebelumnya. Oleh karena alasan tersebut, maka penulis akan melakukan riset untuk memprediksi jumlah mahasiswa di Fakultas Teknik Universitas Asahan.

Berdasarkan latar belakang permasalahan di atas, maka penulis melalukan penelitian dengan judul "Prediksi Perilaku Pola Jumlah Mahasiswa Menggunakan Jaringan Syaraf Tiruan dengan Metode Backpropagation (Studi Kasus di Fakultas Teknik Universitas Asahan)".

\subsection{Kecerdasan Buatan (Artificial Intelligence)}

Kecerdasan buatan atau Artificial Intelligence merupakan salah satu bagian dari ilmu komputer yang mempelajari bagaimana membuat mesin komputer dapat melakukan pekerjaan seperti dan sebaik yang dilakukan oleh manusia bahkan bisa lebih baik daripada yang dilakukan manusia (Dahria, 2008).

\subsection{Jaringan Syaraf Buatan}

Jaringan Syaraf Tiruan adalah merupakan salah satu representasi buatan dari otak manusia yang 
selalu mencoba untuk mensimulasikan proses pembelajaran pada otak manusia tersebut. Istilah buatan di sini digunakan karena jaringan syaraf ini diimplementasikan dengan menggunakan program komputer yang mampu menyelesaikan sejumlah proses perhitungan selama proses pembelajaran (Andrijasa dan Mistianingsih, 2010).

Siang (2009) dalam bukunya menjelaskan bahwa Jaringan Syaraf Tiruan dibentuk sebagai generalisasi model matematika dari jaringan syaraf biologi dengan asumsi-asumsi sebagai berikut :

1. Pemrosesan informasi terjadi pada banyak elemen sederhana (neuron).

2. Sinyal dikirimkan di antara neuron-neuron melalui jalur penghubung.

3. Penghubung antar neuron memiliki bobot yang akan memperkuat atau memperlemah sinyal.

4. Untuk menentukan output, tiap neuron menerapkan fungsi aktivasi (biasanya nonlinier) yang menjumlahkan semua input yang diterima.

Siang (2009) juga menjabarkan tentang tiga hal untuk menentukan Jaringan Syaraf Tiruan, yaitu

1. Pola hubungan antar neuron (disebut arsitektur jaringan).

2. Metode untuk menentukan bobot penghubung (disebut metode training/learning/algoritma).

3. Fungsi aktivasi, yaitu fungsi yang digunakan untuk menentukan keluaran suatu neuron.

Sedangkan, karakteristik dari Jaringan Syaraf Tiruan yang dijelaskan oleh Sangadji (2009) antara lain :

1. Memiliki kemampuan menghasilkan output terhadap pola yang belum pernah dipelajari.

2. Memiliki kemampuan untuk memproses input yang terdapat kesalahan di dalamnya dengan tingkat toleransi tertentu.

3. Mampu beradaptasi dengan perubahan yang terjadi terhadap nilai-nilai input dan output.
Bentuk adaptasi ini diwujudkan dalam perubahan nilai bobot.

4. Akurasi prediksi pada umumnya cukup tinggi.

5. Memerlukan waktu yang relatif lama dalam pembelajaran.

\subsection{Backpropagation}

Menurut Febrianto dan Mustafidah (2013), Backpropagation merupakan algoritma pembelajaran yang terwaris dan biasanya digunakan oleh Perceptron dengan banyak lapisan untuk mengubah bobot-bobot yang terhubung dengan neuron-neuron yang ada pada lapisan tersembunyinya. Sedangkan Sangadji menjelaskan bahwa algoritma Backpropagation ini termasuk metode pelatihan supervised dan didesain untuk operasi pada jaringan feed forward multi layer. Algoritma ini juga dipakai pada aplikasi pengaturan karena proses pelatihannya didasarkan pada hubungan yang sederhana. Jika keluaran memberikan hasil yang salah, maka bobot penimbang (W) dikoreksi agar galatnya dapat diperkecil dan respon jaringan selanjutnya diharapkan akan mendekati hasil sesuai target serta memperbaiki bobot penimbang pada lapisan tersembunyi (hidden layer).

Algoritma pembelajaran Jaringan Syaraf Tiruan Backpropagation yang diformulasikan oleh Puspasari dan Sucipta (2012) secara singkat adalah :

1. Inisialisasi bobot yang dapat dilakukan secara acak.

2. Tiap neuron menghitung nilai aktivasi dari input yang diterimanya. Pada lapisan input, nilai aktivasi adalah fungsi identitas. Pada lapisan tersembunyi dan output, nilai aktivasi dihitung melalui fungsi aktivasi.

3. Penyesuaian bobot dipengaruhi oleh besarnya nilai galat antara target output dan nilai output jaringan saat ini.

4. Iterasi akan terus dilakukan sampai kriteria galat minimum tertentu dipenuhi. 

berikut :

Sumijan dan Santony (2012) mendeskripsikan fase-fase algoritma Backpropagation sebagai

1. Initialitation

Pada fase yang pertama ini yang harus dilakukan adalah set nilai awal untuk variabel-variabel yang diperlukan.

2. Activation

Menghitung output aktual pada hidden layer dengan rumus :

$\mathbf{Y}_{j}(P)=$ fungsi $\left[\sum_{i=1}^{n} X_{i j}(P) \cdot W_{i j}(P)-\theta_{j}\right]$

Menghitung output aktual pada output layer dengan rumus :

$\mathbf{Y}_{k}(P)=$ fungsi $\left[\sum_{j=1}^{m} Y_{j k}(P) \cdot W_{j k}(P)-\theta_{k}\right]$

3. Weight Training

Menghitung error gradient pada output layer dengan rumus :

$\delta_{k}(P)=Y_{k}(P) \times\left[1-Y_{k}(P)\right] \times e_{k}(P)$

Meng-update bobot dari hidden layer ke output layer dengan rumus :

$\mathbf{W}_{\mathrm{jk}}(\mathbf{P}+\mathbf{1})=\mathbf{W}_{\mathrm{jk}}(\mathbf{P})+\Delta \mathbf{W}_{\mathrm{jk}}(\mathbf{P})$

Di mana :

$\Delta \mathbf{W}_{\mathbf{j k}}(\mathbf{P})=\boldsymbol{\alpha} * \mathbf{Y}_{\mathbf{j}}(\mathbf{P}) * \boldsymbol{\delta}_{\mathbf{k}}(\mathbf{P})$

Menghitung error gradient pada hidden layer dengan rumus :

$\delta_{j}(P)=\mathbf{Y}_{j}(P) \times\left[1-\mathbf{Y}_{j}(P)\right] \times \sum_{\mathrm{k}=1}^{\mathrm{e}} \boldsymbol{\delta}_{\mathrm{k}}(\mathbf{P}) \times \mathbf{W}_{\mathrm{jk}}(\mathrm{P})$

Meng-update bobot dari input ke hidden layer dengan rumus :

$\Delta \mathbf{V}_{\mathrm{ij}}(\mathbf{P})=\boldsymbol{\alpha} * \mathbf{X}_{\mathrm{i}}(\mathbf{P}) * \boldsymbol{\delta}_{\mathbf{j}}(\mathbf{P})$

4. Iteration

Ulangi sampai proses error yang diharapkan ditemukan, lalu kembali ke langkah yang ke 2 .

1.4 Prediksi

Pada umumnya, prediksi sebenarnya memperkirakan sesuatu yang akan terjadi di masa yang akan datang berdasarkan data-data sebelumnya. Hasil dari prediksi tersebut tidaklah $100 \%$ benar tetapi mendekati. Oleh karena itu, biasanya digunakan untuk meminimalkan suatu resiko yang timbul dari suatu masalah yang terjadi, bukan untuk menghindari resiko.

Secara umum, peramalan yang dapat dilakukan oleh Jaringan Syaraf Tiruan adalah peramalan runtut waktu (time series) sebagai input dan target sebagai output. Yang diinginkan pada proses pelatihan adalah data periode sebelum tahun yang akan diramal, data tersebut digunakan untuk menentukan bobot optimal. Setelah bobot optimal didapatkan dari proses pelatihan, bobot-bobot tersebut digunakan untuk menentukan nilai peramalan jika sistem diuji oleh data yang pernah masuk dalam sistem peramalan (Setiawan, 2008).
Ada 4 pola data dalam prediksi (Pakaja Dkk., 2012), yaitu :

1. Trend, yaitu pola data tren menunjukkan pergerakan data cenderung meningkat atau menurun dalam waktu yang lama.

2. Seasonality (musiman), yaitu pola data musiman terbentuk karena faktor musiman, seperti cuaca dan liburan.

3. Cycles (siklus), yaitu pola data siklus terjadi jika variasi data bergelombang pada durasi lebih dari satu tahun dipengaruhi oleh faktor politik, perubahan ekonomi (ekspansi atau kontraksi) yang dikenal dengan siklus usaha.

4. Horizontal/Stasionary/Random variation, yaitu pola yang terjadi jika data berfluktuasi di sekitar nilai rata-rata secara acak tanpa membentuk pola yang jelas, seperti pola musiman trend ataupun siklus. 


\section{METODE PENELITIAN}

Pada dasarnya, suatu penelitian membutuhkan metodologi penelitian yang bertujuan untuk mendapatkan hasil yang diinginkan. Tetapi sebelumnya, harus menentukan metode apa yang akan diterapakan. Pada metodologi penelitian ini akan menjelaskan tentang langkah-langkah penelitian yang akan dilakukan.

Dalam penelitian ini menggunakan Jaringan Syaraf Tiruan model Backpropagation. Penelitian ini disusun sebagai penelitian induktif, yakni mencari dan mengumpulkan data-data langsung dari lapangan, tepatnya data penjualan di Fakultas Teknik. Langkah awal yang akan dilakukan dalam penelitian adalah mengumpulkan data sesuai dengan yang dibutuhkan. Kemudian data tersebut akan diolah untuk menghasilkan output yang diinginkan. Penelitian ini diharapkan dapat meningkatkan $\mathrm{j}$ yang terjadi di Fakultas Teknik.

\section{HASIL DAN PEMBAHASAN}

\subsection{Analisa Kebutuhan Data}

Data training merupakan data yang digunakan untuk memberikan pelatihan pada Jaringan Syaraf Tiruan, sehingga Jaringan Syaraf Tiruan dapat mengenali pola yang ada. Data yang menjadi data input prediksi perilaku pola jumlah mahasiswa diambil dari data pada tahun ajaran $2011 \mathrm{~s} / \mathrm{d} 2013$.

Tabel 3.1 Data Training : Input Jumlah Mahasiwa

\begin{tabular}{|c|c|c|c|}
\hline \multirow{4}{*}{ Tahun } & \multicolumn{3}{|c|}{ Jnput Jumlah Mahasiswa Mahasiswa } \\
\cline { 2 - 4 } & $\begin{array}{c}\text { Teknik } \\
\text { Informatika }\end{array}$ & Teknik Sipil & $\begin{array}{c}\text { Teknik } \\
\text { Mesin }\end{array}$ \\
\hline 2011 & 142 Orang & 29 Orang & 24 Orang \\
\hline 2012 & 130 Orang & 16 Orang & 21 Orang \\
\hline 2013 & 83 Orang & 26 Orang & 20 Orang \\
\hline
\end{tabular}

Selain data input yang ditentukan di atas, data output atau target pun harus ditentukan di mana untuk data output diambil dari jumlah keseluruhan data.

Tabel 3.2 Data Training : Output Jumlah Mahasiswa

\begin{tabular}{|c|c|c|}
\hline \multicolumn{3}{|c|}{ Data Output Jumlah Mahasiswa } \\
\hline \multicolumn{3}{|c|}{ Total Jumlah Mahasiswa } \\
\hline 2011 & 2012 & 2013 \\
\hline 195 Orang & 167 Orang & 129 Orang \\
\hline
\end{tabular}

Sedangkan untuk data pengujian diambil dari data tahun ajaran 2014, 2015 dan 2016 yang akan dijadikan sebagai data input. Data input selama 3 tahun tersebut dijumlahkan yang kemudian akan dijadikan sebagai data output.

Tabel 3.3 Data Pengujian : Input Jumlah Mahasiswa

\begin{tabular}{|c|c|c|c|}
\hline \multicolumn{4}{|c|}{ Input Jumlah Mahasiswa } \\
\hline \multirow{3}{*}{ Tahun } & \multicolumn{3}{|c|}{ Jumlah Mahasiswa } \\
\cline { 2 - 4 } & $\begin{array}{c}\text { Teknik } \\
\text { Informatika }\end{array}$ & $\begin{array}{c}\text { Teknik } \\
\text { Sipil }\end{array}$ & $\begin{array}{c}\text { Teknik } \\
\text { Mesin }\end{array}$ \\
\hline 2014 & 65 Orang & 17 Orang & 20 Orang \\
\hline 2015 & 60 Orang & 15 Orang & 14 Orang \\
\hline 2016 & 56 Orang & 34 Orang & 15 Orang \\
\hline
\end{tabular}


Tabel 3.4 Data Pengujian: Output Jumlah Mahasiswa

\begin{tabular}{|c|c|c|}
\hline \multicolumn{3}{|c|}{ Data Output Jumlah Mahasiswa } \\
\hline \multicolumn{3}{|c|}{ Total Jumlah Mahasiswa } \\
\hline 2014 & 2015 & 2016 \\
\hline 102 Orang & 89 Orang & 105 Orang \\
\hline
\end{tabular}

\subsection{Arsitektur Jaringan Syaraf Tiruan}

Arsitektur Jaringan Syaraf Tiruan yang akan dipergunakan merupakan jaringan syaraf dengan banyak lapisan (Multi-Layer Feedforward Networks) dengan algoritma Backpropagation yang terdiri dari :

1. Lapisan Input, dengan 3 simpul di mana $X_{1}$ merupakan jumlah mahasiswa tahun ajaran 2011, untuk $\mathrm{X}_{2}$ merupakan jumlah mahasiswa 2012, dan $\mathrm{X}_{3}$ merupakan jumlah mahasiswa tahun ajaran 2013.

2. Lapisan Hidden, dengan jumlah simpul yang telah ditentukan oleh penulis, yaitu dua simpul.

3. Lapisan Output, dengan satu simpul, yaitu total keseluruhan jumlah Mahasiswa dan yang diinputkan selama tiga minggu.

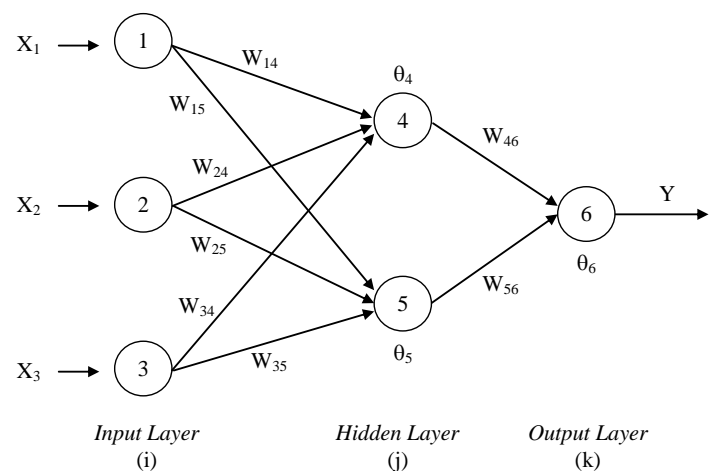

Gambar 3.1 Arsitektur Jaringan Backpropagation dari Prediksi Pola Mahasiswa Terhadap

Arsitektur jaringan yang terbentuk adalah 3-2-1 yang terdiri dari :

$\begin{array}{lll}\mathrm{X} & = & \text { masukan (input) } \\ \mathrm{V} & = & \text { bobot pada lapisan tersembunyi } \\ \mathrm{W} & = & \text { bobot pada lapisan keluaran } \\ \theta & = & \text { threshold } \\ \mathrm{Y} & = & \text { keluaran (output) }\end{array}$

Algoritma yang digunakan adalah algoritma Backpropagation dengan fungsi aktivasi sigmoid yang memiliki rentang interval 0 dan 1 .

\subsection{Normalisasi Data}

Sebagai data sampel adalah data mahasiswa yang terdiri dari jumlah mahasiswa dengan jumlah data yang digunakan untuk menguji keakuratan sistem di dalam mengenali masukan data yang lain. Untuk pola input-nya adalah sebagai berikut
1. Jumlah mahasiswa tahun ajaran 2011 disimpan pada variabel $\mathrm{X}_{1}$.

2. Jumlah mahasiswa tahun ajaran 2012 disimpan pada variabel $\mathrm{X}_{2}$.

3. Jumlah mahasiswa tahun ajaran 2013 disimpan pada variabel $\mathrm{X}_{3}$

Dalam Jaringan Syaraf Tiruan dengan Backpropagation ini akan menggunakan fungsi aktivasi sigmoid (biner). Oleh karena itu, data harus ditransformasikan dulu karena range keluaran fungsi aktivasi sigmoid adalah antara 0 dan 1. Data bisa ditransformasi ke interval 0 dan 1. Tapi akan lebih baik jika ditransformasikan ke interval yang lebih kecil, yaitu pada interval 0,1 dan 0,9. Ini mengingat fungsi sigmoid merupakan fungsi asimtotik yang nilainya tidak pernah mencapai 0 ataupun 1 . 
Tabel 3.5 Data Training : Input dan Output Jumlah Mahasiswa yang Ditransformasikan

\begin{tabular}{|c|c|c|c|}
\hline \multicolumn{3}{|c|}{ Jumlah Mahasiswa } \\
\cline { 1 - 2 } $\mathrm{X}_{\mathrm{i}}$ & \multirow{2}{*}{$\mathrm{T}$} \\
\hline $\mathrm{X}_{1}$ & $\mathrm{X}_{2}$ & $\mathrm{X}_{3}$ & \\
\hline 0,90 & 0,90 & 0,35 & 0,90 \\
\hline 0,74 & 0,30 & 0,30 & 0,56 \\
\hline 0,10 & 0,10 & 0,10 & 0,10 \\
\hline
\end{tabular}

Tabel 3.6 Data Pengujian : Input dan Output Jumlah Mahasiswa yang Ditransformasikan

\begin{tabular}{|c|c|c|c|}
\hline \multicolumn{3}{|c|}{ Jumlah Mahasiswa } \\
\cline { 1 - 2 } $\mathrm{X}_{1}$ & $\mathrm{X}_{2}$ & $\mathrm{X}_{3}$ & $\mathrm{~T}$ \\
\hline 0,90 & 0,90 & 0,18 & 0,75 \\
\hline 0,46 & 0,10 & 0,10 & 0,10 \\
\hline 0,10 & 0,23 & 0,90 & 0,90 \\
\hline
\end{tabular}

Proses untuk mengelola data training sehingga Jaringan Syaraf Tiruan dapat mengenali pola data tersebut berdasarkan target yang telah ditentukan, maka dilakukan langkah-langkah sebagai berikut :

\section{Tahap Initialization}

Memberikan nilai awal terhadap variabelvariabel yang diperlukan, seperti nilai $\left(\mathrm{X}_{\mathrm{i}}\right)$, bobot $\left(\mathrm{W}_{\mathrm{i}}\right)$, target $\left(\mathrm{Y}_{\mathrm{d}}\right)$, learning rate $(\alpha)$, dan threshold $(\theta)$.

\section{Tahap Activation}

Pada tahap ini dilakukan dua kegiatan, yaitu menghitung output aktual pada hidden layer dan menghitung output aktual pada output layer.

3. Tahap Weight Training
Pada tahap ini dilakukan empat kegiatan, yaitu menghitung error gradient pada output layer, meng-update bobot dari hidden ke output layer, menghitung gradient pada hidden layer, dan mengupdate bobot dari input ke hidden layer.

\section{Tahap Iteration}

Proses pengulangan ke langkah-langkah sebelumnya sampai dengan error yang ditetapkan tercapai.

\subsection{Pengujian Data Mahasiswa}

Untuk menguji akurasi pelatihan jaringan syaraf tiruan digunakan beberapa model arsitektur jaringan saraf tiruan yaitu, 3-2-1.

Berikut ini ditampilkan hasil pelatihan jaringan syaraf tiruan dari model-model tersebut.

Tabel 3.7 Pengujian Arsiterktur 3-2-1 Data Pelatihan Jumlah Mahasiswa

\begin{tabular}{|c|c|c|c|c|c|c|c|c|c|}
\hline \multicolumn{4}{|c|}{ Jumlah Mahasiswa } & \multicolumn{6}{|c|}{ Pengujian pada Matlab } \\
\hline \multicolumn{3}{|c|}{$\mathrm{X}_{\mathrm{i}}$} & \multirow{2}{*}{$\mathrm{T}$} & \multicolumn{3}{|c|}{ Iterasi 1} & \multicolumn{3}{|c|}{ Iterasi Terakhir } \\
\hline $\mathrm{X}_{1}$ & $\mathrm{X}_{2}$ & $\mathrm{X}_{3}$ & & $\mathrm{Y}$ & Error & Perf & $\mathrm{Y}$ & Error & Perf \\
\hline 0,90 & 0,90 & 0,35 & 0,90 & 0,9217 & $-0,0217$ & \multirow{3}{*}{0,2861} & 0,8190 & 0,0810 & \multirow{3}{*}{0,0100} \\
\hline 0,74 & 0,30 & 0,30 & 0,56 & 0,9389 & $-0,3789$ & & 0,0367 & 0,0367 & \\
\hline 0,10 & 0,10 & 0,10 & 0,10 & 0,9452 & $-0,8452$ & & 0,2486 & $-0,1486$ & \\
\hline
\end{tabular}


Berikut ini ditampilkan hasil pelatihan jaringan syaraf tiruan dari model-model tersebut.

\subsection{Hasil Pengujian}

Dari hasil pengujian dengan arsitektur Jaringan Syaraf Tiruan pada data training di atas, maka didapatkan beberapa nilai error untuk jumlah mahasiswa sehingga dapat dilihat mana nilai error terkecil dan terbesar.

Tabel 3.8 Nilai Error dari Pengujian Jumlah Mahasiswa

\begin{tabular}{|c|c|}
\hline No. & $\begin{array}{c}\text { Arsitektur Jaringan Syaraf } \\
\text { Tiruan }\end{array}$ \\
\hline 1 & 0,0810 \\
\hline 2 & 0,0367 \\
\hline 3 & $-0,1486$ \\
\hline Total Error & $-0,0309$ \\
\hline $\begin{array}{c}\text { Rata-Rata } \\
\text { Error }\end{array}$ & $-0,0103$ \\
\hline Max Error & 0,0810 \\
\hline Min Error & $-0,1489$ \\
\hline
\end{tabular}

Dari tabel 3.8 di atas terlihat bahwa rata-rata error yang terkecil adalah menggunakan arsitektur jaringan $-0,1489$.

\subsection{Pengujian Data Testing untuk Jumlah Mahasiswa}

Dari hasil pengujian data training untuk jumlah Mahasiswa maka arsitektur yang terbaik adalah arsitektur jaringan 3-2-1 maka untuk pengujian data testing ini menggunakan arsitektur jaringan 3-2-1.

Tabel 3.9 Pengujian Arsiterktur 3-2-1 Data Pengujian Jumlah Mahasiswa

\begin{tabular}{|c|c|c|c|c|c|c|}
\hline \multicolumn{3}{|c|}{ Jumlah Mahasiswa } & \multicolumn{3}{|c|}{ Pengujian pada Matlab } \\
\hline \multicolumn{3}{|c|}{$\mathrm{X}_{\mathrm{i}}$} & $\mathrm{T}$ & $\mathrm{Y}$ & Error & Perf \\
\cline { 1 - 3 } & $\mathrm{X}_{1}$ & $\mathrm{X}_{3}$ & & $\mathrm{Y}$ & \\
\hline 0,90 & 0,90 & 0,18 & 0,75 & 0,5697 & 0,1603 & \\
\hline 0,46 & 0,10 & 0,10 & 0,10 & 0,3168 & 0,2168 & \multirow{2}{*}{0,2045} \\
\hline 0,10 & 0,23 & 0,90 & 0,90 & 0,1646 & 0,7354 & \\
\hline
\end{tabular}

Tabel 3.10 Perbandingan Jumlah Mahasiswa Aktual dan Prediksi

\begin{tabular}{|l|c|}
\hline \multicolumn{2}{|c|}{ Jumlah Prediksi Mahasiswa } \\
\hline Teknik Informatika & 0,5697 \\
\hline Teknik Sipil & 0,3168 \\
\hline Teknik Mesin & 0,1646 \\
\hline
\end{tabular}

3.8 Hubungan Prediksi Prilaku Pola Jumlah Mahasiswa

Hubungan prediksi prilaku pola mahasiswa terlihat pada gambar 3.2 berikut. 


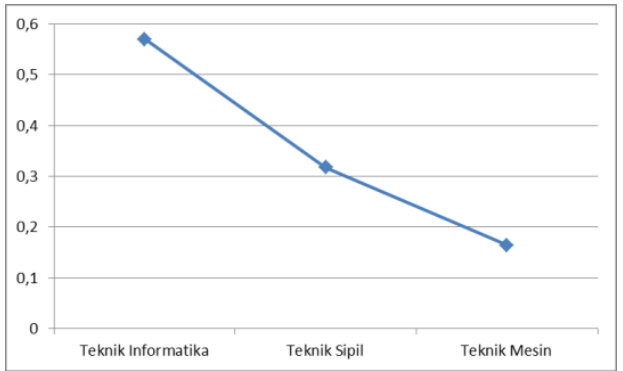

Gambar 3.2 Grafik Prediksi Pola Jumlah Mahasiswa

Dari gambar di atas menunjukkan prediksi dari jumlah mahasiswa pada masing-masing Program Studi di Fakultas Teknik Universitas Asahan.

\section{KESIMPULAN}

Berdasarkan penelitian, implementasi, dan pengujian maka dapat diambil kesimpulan secara umum sebagai berikut :

1. Prediksi jumlah mahasiswa dapat menjawab permasalahan kaitan antara jumlah mahasiswa pada masing-masing Program Studi pada masa yang akan datang.

2. Tidak hanya pola yang terlihat dari hasil pelatihan, ternyata model juga menggambarkan pola jumlah mahasiswa pada masing-masing Program Studi. Hal ini dapat dijadikan pertimbangan tentang promosi-promosi tertentu.

\section{DAFTAR PUSTAKA}

[1] Iriansyah BM Sangadji (2009). "Prediksi Perilaku Pola Mahasiswa Terhadap Pada Toko Buku Gramedia Menggunakan Jaringan Syaraf Tiruan Metode Back Propagation." Jurnal Informatika. 5. 135150.

[2] Muhammad Dahria (2008). "Kecerdasan Buatan (Artificial Intelligence)." Jurnal Saintikom. 5. 185-196.

[3] Sumijan dan Julius Santony (2012). "Jaringan Syaraf Tiruan menggunakan Algoritma Backpropagation Untuk Memprediksi Prestasi Mahasiswa di Lingkungan Kopertis Wilayah X (Sumbar, Riau, Jambi dan Kepri).” Seminar Nasional Teknologi Informasi Universitas Diponegoro Semarang.
Shinta Puspasari dan Alfan Sucipta (2012). "Analisis Implementasi Algoritma Propagasi Balik Pada Aplikasi Identifikasi Wajah Secara Waktu Nyata." Prosiding Seminar Ilmiah Nasional Komputer dan Sistem Intelijen (KOMMIT 2012). 7. 405411.

Wahyudi Setiawan (2008). "Prediksi Harga Saham Menggunakan Jaringan Syaraf Tiruan Multilayer Feedforward Network Dengan Algoritma Backpropagation." Konferensi Nasional Sistem dan Informatika. 108-113. 